January 2001

\title{
Getting Serious about Corporate Tax Shelters: Taking a Lesson from History
}

George K. Yin

\section{Recommended Citation}

George K. Yin, Getting Serious about Corporate Tax Shelters: Taking a Lesson from History, 54 SMU L. REV. 209 (2001)

https://scholar.smu.edu/smulr/vol54/iss1/13

This Article is brought to you for free and open access by the Law Journals at SMU Scholar. It has been accepted for inclusion in SMU Law Review by an authorized administrator of SMU Scholar. For more information, please visit http://digitalrepository.smu.edu. 


\title{
Getting Serious About Corporate TAX Shelters: TAKING a Lesson FROM HISTORY
}

\author{
George K. Yin*
}

$\mathrm{H}$

OW should the tax system best respond to the problem of corporate tax shelters? To answer that question, the papers in this symposium have sought guidance from diverse sources ranging from the international experience with tax shelters, ${ }^{1}$ the practicing tax bar, ${ }^{2}$ moral philosophy, ${ }^{3}$ and the partnership anti-abuse regulations. ${ }^{4}$ In this paper, I suggest that history might also offer some insight-specifically, the history of tax shelter activity in this country during the 1970's and 1980's, and the tax system's response to that problem.

As a threshold matter, this paper assumes that a serious corporate tax shelter problem currently exists. Despite mounting anecdotal evidence of one, there remains some uncertainty about it; so far, the empirical evidence is quite skimpy. ${ }^{5}$ Nevertheless, respected commentators both inside and outside of government seem persuaded by both the existence of a problem and its significance. ${ }^{6}$ Thus, this paper attempts to address the next question: what should be done about it?

* Howard W. Smith Professor of Law and Barron F. Black Research Professor, University of Virginia. E-mail: gyin@virginia.edu. Copyright (C) 2000 by George K. Yin.

1. Graeme S. Cooper, International Experience with General Anti-Avoidance Rules, 54 SMU L. REV. 83 (2001).

2. Peter C. Canellos, A Tax Practitioner's Perspective on Substance, Form and Business Purpose in Structuring Business Transactions and in Tax Shelters, 54 SMU L. REv. 47 (2001).

3. Ellen P. Aprill, Tax Shelters, Tax Law, and Morality: Codifying Judicial Doctrines, 54 SMU L. REV. 9 (2001).

4. Alan Gunn, The Use and Misuse of Antiabuse Rules: Lessons from the Partnership Antiabuse Regulations, 54 SMU L. REV. 159 (2001).

5. For a careful attempt to separate predictable explanations for corporate book-tax differences from possible corporate tax shelter explanations, see Gil B. Manzon, Jr. \& George A. Plesko, The Relationship Between Financial and Tax Reporting Measures of Income, TAx. L. REv. (forthcoming). See also Martin A. Sullivan, Let the Good Times Roll: Options and Tax-Free Profits, 87 TAx Notes 1185 (2000); George K. Yin, Corporate Tax Shelters and the Exercise of Nonqualified Stock Options (unpublished manuscript).

6. See Hearing on Penalty and Interest Provisions of the Internal Revenue Code Before the U.S. Senate Fin. Comm., 106th Cong., 2d Sess. (2000) (statement of Jonathan Talisman, Acting Assistant Secretary for Tax Policy, U.S. Dept. of Treasury); David Weisbach, It's Time to Get Serious about Shelters, 89 TAx Notes 1677, 1677 (2000) ("almost everyone . . agrees that there is a serious problem with [corporate tax] shelters. The system is broken"); Canellos, supra note 2, at 48 (no citations necessary to establish the fact that corporate tax shelters are both proliferating and increasingly audacious). See generally U.S. Dept. of Treasury, The Problem of Corporate Tax Shelters: Discussion, Analysis and Legis- 
Part I briefly describes the experience in this country with the last major wave of tax shelter activity. It identifies many of the steps taken by the tax system to curb tax shelters and shows that the steps were largely ineffective until 1986.

Part II then explores the key lessons to be learned from the prior experience. It explains why a rule with the same characteristics as section 469 - a broad, reasonably clear, outcomes-oriented rule-is needed if the mistakes made in response to the earlier generation of shelters are to be avoided.

Part III then applies these lessons to the corporate tax shelter problem and outlines the advantages and disadvantages of two possible responses to that problem. First, it considers the enactment of an "anti-abuse" rule which denies a particular tax result if no sensible legislator would have approved of the result at the time the statute was drafted. Next, it explores the possibility of taxing public corporations on their income reported for financial accounting purposes, as adjusted by tax rules authorizing specific deviations from that base.

Part IV contains my conclusions. I find that the uncertainty of an antiabuse rule would likely undermine its ability to be an effective deterrent to corporate tax shelters. On the other hand, if the corporate tax shelter problem is as serious as many now claim, $I$ argue that a change to an adjusted book income tax base for public corporations deserves further consideration.

\section{THE LAST WAR AGAINST TAX SHELTERS.}

\section{A. Growth and Decline of Tax Shelter Activity Since 1975}

This section provides evidence of the changing level of tax shelter activity engaged in by individuals since 1975 . Because many tax shelter investments of individuals during the late 1970's and the 1980's were carried out through partnerships, ${ }^{7}$ the first two sets of time series data focus on tax information arising from such ventures. This data presents the tax items reported by the individual owners of the ventures and by the ventures themselves. The third set of data then examines the level of tax shelter activity as shown by the administrative impact of the activity on the U.S. Tax Court and the IRS. Taken together, the data indicates that there was a growth in tax shelter activity engaged in by individuals until approximately 1986 and a decline since that time.

\section{Data Reported by Owners of Partnerships and S Corporations}

Figure 1 shows the net income or net loss reported by individual taxpayers from their partnership and $S$ corporation investments over the pe-

lative Proposals, available at http://www.treas.gov/taxpolicy/corptaxshelter.html (1999) [hereinafter Treasury White Paper].

7. See U.S. J. Comm. on Tax'n, Overview of Tax Shelters, JCS-22-75 (Comm. Print 1975) [hereinafter JCT-Overview]. 
riod, 1975 through $1997 .{ }^{8}$ The total amount of net losses reported grew $525.8 \%$ between 1975 and 1986 , much faster than the $136.9 \%$ increase in the total amount of net income reported. The growth in losses is consistent with an increase in tax shelter activity during that period. Beginning in 1981 and continuing until 1986, net losses reported exceeded net income. These trends reversed beginning in 1987 when net income reported increased by $38.1 \%$ from 1986 and was greater than net loss reported, which declined by $17.5 \%$ from 1986 . During the period 1986 through 1997, the net income reported by individual taxpayers from partnership and S corporation investments grew by $307.5 \%$ while the net losses reported by such taxpayers from the same investments decreased by $22.4 \% .^{9}$ The increase in net income reported during this period indicates that the decline in net loss reported was not due to a reduction in the amount of partnership and $\mathrm{S}$ corporation investment by individuals. Rather, it suggests that there may have been a change in the type of investments made, from tax shelters to more economically-oriented ventures.

Figure 2 shows the number of individual income tax returns reporting partnership and S corporation income or loss between 1975 and 1997.10 The trend is similar to Figure 1. From 1975 to 1986, the number of tax returns reporting net losses increased by $170.9 \%$, much more than the $36.1 \%$ increase in the number of returns reporting net income. The increase in the number of returns reporting losses is contrary to normal market expectations and suggests that some amount of the losses may have been non-economic or tax shelter losses. ${ }^{11}$ From 1986 to 1997, the number of returns reporting net losses from partnership and $\mathrm{S}$ corporation investments declined by $35.7 \%$ whereas the number of returns reporting net income grew by $55.1 \%$.

8. Since 1985 , the IRS has provided data which aggregates the partnership and $S$ corporation income or loss reported by individual owners. Data from the 10 years prior to 1985 (when the partnership and S corporation information was provided separately) indicates that the $S$ corporation share of those items was pretty consistently between 17 and 22 percent of the total of each item. See IRS, Statistics of Income, Individual Income Tax Returns, $1975-76$ (tbl. 1.6), 1977-78 (tbl. 1.3), 1979-81 (tbl. 1.2), 1982-83 (tbl. 1.3), 1984-97 (tbl. 1.4).

9. The difference between net income and net loss reported since 1986 is actually more dramatic than these figures indicate due to a change in the reporting of tax items. In 1987, portfolio income of pass-through entities, such as interest, dividends, and royalties, began to be reported separately by the owners of such entities and was not netted with the other income or loss passed through to and reported by them. See Susan Nelson \& Tom Petska, Partnerships, Passive Losses, and Tax Reform, 9 SOI Bulletin 31, 38 n.15 (Winter 1989-90). Thus, since 1987, pass-through net income is understated and pass-through net loss is overstated relative to the manner such amounts were previously reported and shown on Figure 1.

10. The disaggregated figures from prior to 1985 show that the number of individual taxpayer returns reporting $S$ corporation income or loss was between 17 and 20 percent of the total of each category. See supra note 8.

11. See Nelson \& Petska, supra note 9, at 33; Tom Petska, Partnerships, Partners, and Tax Shelters After Tax Reform, 1987-1989, 12 SOI Bulletin 8, 11 (Summer 1992). 


\section{Data Reported by Limited Partnerships and LLCs}

Although Figures 1 and 2 indicate that the amount of tax benefits as well as the number of individual investors reporting losses from partnership and S corporation investments have declined since 1986, the numbers do not necessarily reflect any change in the level of tax shelter activity. It is possible that the level of activity has continued at the same pace as prior to 1986 , with some overriding tax rule (such as the passive activity loss rules) preventing the claiming of the resulting tax benefits by the individual owners of the pass-through entities. Deductions and losses passed through by the entities, for example, might simply be suspended by the passive activity loss rules in increasing amounts. ${ }^{12}$

Figure 3, however, provides evidence that the level of tax shelter activity engaged in by individuals has, in fact, declined since 1986. Figure 3 shows the amount of net income or loss reported by limited partnerships, the single most popular vehicle for tax shelter investments by individuals, ${ }^{13}$ over the period 1981-97. ${ }^{14}$ (Data from LLCs is aggregated with the limited partnership data beginning in 1993 when meaningful amounts of LLC income or loss were first reported to the IRS.) Thus, this data should reflect the type of investments made by limited partnerships during this period, regardless of whether any resulting tax benefits passed through to the owners could actually be claimed by them.

Between 1981 and 1986, net losses reported by limited partnerships increased by $122.6 \%$, or roughly the same as the $115.4 \%$ increase in net income reported by them. In contrast, from 1986 to 1996, during which time net income from limited partnerships and LLCs increased over $600 \%$, net losses reported were essentially unchanged. These facts strongly support the view that there was a shift in the nature of investments undertaken by limited partnerships since 1986, with a reduction in the amount of tax sheltered investments.

Figure 4, which shows the number of limited partnerships and LLCs reporting net income or loss between 1981 and 1997, is consistent with that view. The number of limited partnerships reporting losses increased by $36.1 \%$ from 1981 to 1986 , somewhat similar to the $22.7 \%$ increase in the number of limited partnerships reporting net income. From 1986 to 1995 , however, the trend was much different: the number of limited partnerships and LLCs reporting income increased by $135.9 \%$ whereas the number reporting losses increased by a mere $8.8 \%$.

Somewhat surprisingly, Figure 4 also shows that between 1995 and 1997, there was a sharp upsurge in the number of limited partnerships

12. See I.R.C. $\S 469$ (b). All Code references are to the Internal Revenue Code of 1986 , as amended.

13. See JCT-Overview, supra note 7 , at 5 .

14. For the precise definition of the items included in partnership and LLC net income or loss, see Alan Zempel, Partnership Returns, 1997, 19 SOI Bulletin 46, 58 (Fall 1999); Timothy D. Wheeler, Partnership Returns, 1991, 13 SOI BulletrN 80, 92 (Fall 1993). This data is unavailable for periods prior to 1981 . 
and LLCs reporting losses. "Loss" firms increased by $53.8 \%$ during that period, almost as much as the increase in "income" firms $(72.8 \%)$. To examine whether this recent trend might indicate a revival of tax shelter activity, Figure 5 presents the same data as Figure 4 except that the limited partnership and LLC information is disaggregated. Figure 5 indicates that the number of loss limited partnerships, alone, actually fell between 1995 and 1997 with the entire increase in the aggregate number of loss firms being attributable to the LLCs. There was a dramatic and almost identical increase in the number of LLCs reporting net income and those reporting net loss, with each category increasing by almost 200\% between 1995 and 1997.

To some extent, the LLCs with losses may be new, start-up firms with the losses representing economic losses typically incurred by such firms rather than tax shelter losses. Some support for this possibility is provided by Figure 6, which shows the number of limited partners and LLC members of limited partnerships and LLCs reporting either net income or loss between 1981 and 1997. This figure depicts the same pattern seen previously-a $100 \%$ increase in the number of limited partners of loss limited partnerships between 1981 and 1986 , followed by a $36 \%$ decrease in such number between 1986 and 1997. More significantly, Figure 6 shows that there was a relatively small increase of about 450,000 in the number of LLC members of loss LLCs between 1995 and 1997. During the same period, the number of loss LLCs grew by about 112,000 (see Figure 5). These two figures indicate that most of the loss LLCs had very few members, including perhaps many with but a single owner. This finding is consistent with the hypothesis that the loss LLCs may represent new, start-up businesses incurring economic losses.

\section{Data Involving Income Tax Administration}

Change in the level of tax shelter activity is also reflected by the impact such activity had on income tax administration. Between 1979 and 1986, the annual number of tax shelter returns under examination by the IRS more than doubled from 182,731 to $426,634 .{ }^{15}$ By 1989 , the number had fallen back to $108,899 .{ }^{16}$ There was a similar change in the number of tax shelter cases in the IRS Appeals Division. For example, in 1986, there were 40,200 new tax shelter cases received by the Appeals Division, representing approximately $44 \%$ of all new cases received by that office. ${ }^{17}$ By 1990 , there were only 4,824 new tax shelter cases received, or only about $7.8 \%$ of the office's total new workload. ${ }^{18}$

Figure 7 shows the change in the number of cases docketed in the U.S. Tax Court from 1981 through 1993. The caseload peaked at almost 88,000

15. I.R.S. 1980 Annual RePORT 27; Tax Shelters: IRS Settlement Policy Will Continue Without Regard to Backlog of Cases, Chief Counsel Says, BNA DaILY TAX REPORT, Dec. 8,1986 , at G-1.

16. I.R.S. 1989 ANNUAL Report 14

17. I.R.S. 1986 ANNUAL RePORT 58.

18. I.R.S. 1990 ANNUAl Report 41. 
cases in 1987, a 93\% increase from 1981. By 1993, the caseload had declined back to roughly its 1981 level. Although precise figures are unavailable to show what proportion of these cases represented tax shelter cases, it appears that tax shelters were a significant cause of the increase. For example, over $50 \%$ of the caseload during three of the peak years, 1986-88, was from tax shelter litigation. ${ }^{19}$

\section{Summary}

The data contained in this section indicates that since 1975 , there has been a change in the level of tax shelter activity engaged in by individuals. The level of activity increased until 1986 and has decreased since that time.

\section{B. Tax System Responses to Tax Shelters}

During the 1970's and 1980's, all three branches of government were very active in attempting to curb tax shelters. The legislative branch was especially active. Virtually every major tax act between 1969 and 1986 contained one or more significant pieces of legislation designed to prevent the proliferation of tax shelters. The new legislation included the following:

- many changes to the substantive tax law, including significant tightening of the depreciation recapture rules, ${ }^{20}$ revision of the partnership special allocation rules, ${ }^{21}$ and enactment of the add-on and alternative minimum taxes, ${ }^{22}$ the limitations on investment interest ${ }^{23}$ and prepaid interest, ${ }^{24}$ the at-risk rules, ${ }^{25}$ the straddle rules, ${ }^{26}$ the OID rules, ${ }^{27}$ and the passive activity loss rules; ${ }^{28}$

- changes in tax procedure, such as enactment of the TEFRA partnership audit rules ${ }^{29}$ and authorization of injunctive action against promoters of abusive tax shelters; ${ }^{30}$

- many penalty provisions against taxpayers or third parties, including the valuation overstatement penalty, ${ }^{31}$ the substantial understatement penalty, ${ }^{32}$ and the penalties for promoting abusive tax shelters ${ }^{33}$ and failing to furnish information regarding tax shelters; ${ }^{34}$ and

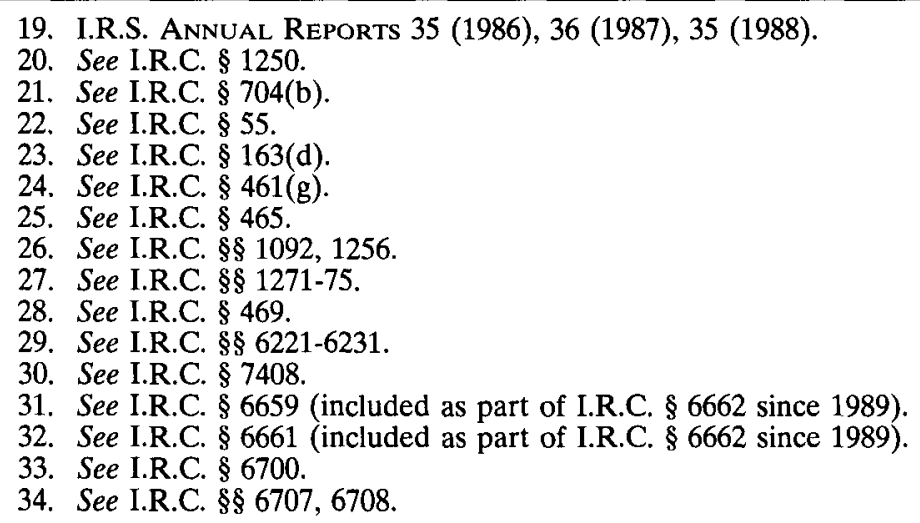


- new compliance, registration and disclosure requirements, such as the reporting of certain real estate transactions, ${ }^{35}$ promoter registration of tax shelters, ${ }^{36}$ and required maintenance of investor lists by organizers and sellers of tax shelters. ${ }^{37}$

In addition to working with the Congress in the enactment of the new legislation and promulgating regulations pursuant to it, the executive branch issued a number of interpretative rulings in the tax shelter area. ${ }^{38}$ The Treasury Department also adopted changes to Circular 230, the administrative rules for practice before the IRS, to try to rein in more aggressive tax practitioners providing tax advice on tax shelter investments. ${ }^{39}$

Finally, the judicial branch was also active during this period, with the leading tax shelter cases being Franklin's Estate v. Commissioner, ${ }^{40}$ Frank Lyon Co. v. United States, ${ }^{41}$ Hilton v. Commissioner, ${ }^{42}$ Commissioner v. Tufts, ${ }^{43}$ Odend'hal v. Commissioner, ${ }^{44}$ Rice's Toyota World, Inc. v. Commissioner, ${ }^{45}$ United States v. Philatelic Leasing, Ltd. ${ }^{46}$ Yosha v. Commissioner, ${ }^{47}$ Pleasant Summit Land Corp. $v$. Commissioner, ${ }^{48}$ Rose $v$. Commissioner, ${ }^{49}$ and Sheldon v. Commissioner. ${ }^{50}$ Important earlier precedents included Gregory v, Helvering, ${ }^{51}$ Knetsch v. United States, ${ }^{52}$ and Goldstein v. Commissioner. ${ }^{53}$

\section{LESSONS FROM THE LAST WAR AGAINST TAX SHELTERS}

\section{A. The Problem with Incremental Reform}

The foregoing brief description of the tax system's response to tax shelters during the 1970's and 1980's, which captures only a few highlights of that period, explains why many observers have a strong sense of déjà vu regarding the anti-tax shelter actions being proposed and taken today. In recent years, concern about corporate tax shelters has again evoked a

35. See I.R.C. \& 6045(e).

36. See I.R.C. § 6111 .

37. See I.R.C. \& 6112.

38. See JCT-Overview, supra note 7 , at 18-22 for a description of positions taken by the IRS and the SEC during the early 1970's to restrict tax shelter activity.

39. See 31 C.F.R. $\S 10.33$ (1999).

40. 544 F.2d 1045 (9th Cir. 1976).

41. 435 U.S. 561 (1978).

42. 74 T.C. 305 (1980), aff'd per curiam, 671 F.2d 316 (9th Cir. 1982), cert. denied, 459 U.S. 907 (1982).

43. 461 U.S. 300 (1983).

44. 748 F.2d 908 (4th Cir. 1984).

45. 752 F.2d 89 (4th Cir. 1985).

46. 794 F.2d 781 (2d Cir. 1986).

47. 861 F.2d 494 (7th Cir. 1988).

48. 863 F.2d 263 (3d Cir. 1988).

49. 868 F.2d 851 (6th Cir. 1989).

50. 94 T.C. $738(1990)$.

51. 293 U.S. 465 (1935).

52. 364 U.S. $361(1960)$.

53. 364 F.2d 734 (2d Cir. 1966), cert. denied, 385 U.S. 1005 (1967). 
response from all three branches of government. The Treasury Department has been especially active in issuing a host of regulations, rulings, and other administrative pronouncements, ${ }^{54}$ and several judicial decisions have been issued. ${ }^{55}$ Congress has enacted some new legislation ${ }^{56}$ and it may be only a matter of time before more significant legislative action is taken.

What additional steps should be done? There have been calls for further modifications of substantive law, increased penalties, new disclosure and other compliance requirements, and amendment of the Circular 230 standards, among other things. ${ }^{57}$ Yet, as we have seen, many of those same steps were taken during the 1970's and early 1980's without any perceptible impact on the level of tax shelter activity. Tax shelters were not effectively curbed until 1986.

There are at least two worries about repeating the types of steps taken in response to the last generation of tax shelters. First, incremental changes in the law intended to stem inefficient tax shelter activity may result instead in greater inefficiency and distortion. This will occur if taxpayers and the government engage in what might be referred to as the Tax Avoidance (or "T.A.") game: The government first identifies a transaction or an outcome that it considers inappropriate and moves to prevent it through some change in the law. If, subsequent to the change, taxpayers still perceive the after-tax return from their desired outcome to be greater than the costs necessary to achieve that outcome, they may respond by attempting to circumvent the change in law. For example, they may explore alternative means of achieving their desired outcome which may be less direct and more expensive than the original technique, yet still worthwhile. Or, they may discover and try to take advantage of crevices in the new law to reach their original goal or attain an even better one. ${ }^{58}$ The government eventually discovers and responds to these

54. See, e.g., Not. 2000-61, 2000 WL 1729184; Not. 2000-6, 2000 WL 1720833; Not. 2000-44, 2000-36 I.R.B. 1; T.D. 8875, 2000-11 I.R.B. 761; T.D. 8876, 2000-11 I.R.B. 753; T.D. 8877, 2000-11 I.R.B. 747; Ann. 2000-51, 2000-22 I.R.B. 1141; Ann. 2000-12, 2000-12 I.R.B. 835; Not. 2000-15, 2000-12 I.R.B. 826; Rev. Rul. 2000-12, 2000-11 I.R.B. 744; T.D. 8853, 2000-4 I.R.B. 377; Rev. Rul. 99-14, 1999-13 I.R.B. 3; Not. 99-59, 1999-52 I.R.B. 761; Not. $98-5,1998-1$ C.B. 334.

55. See, e.g., ACM P'ship v. Comm'r., 73 T.C.M. (CCH) 2189 (1997), aff'd in part and rev'd in part, 157 F.3d 231 (3d Cir. 1998), cert. denied, 526 U.S. 1017 (1999); ASA Investerings P'ship v. Comm'r., 76 T.C.M. (CCH) 325 (1998), aff'd, 201 F.3d 505 (D.C. Cir. 2000), cert. denied, 121 S. Ct. 171 (2000); Compaq Computer Corp. v. Comm'r., 113 T.C. 214 (1999); Winn-Dixie Stores v. Comm'r., 113 T.C. 254 (1999); UPS v. Comm'r., 78 T.C.M. (CCH) 262 (1999); Saba P'ship v. Comm'r., 78 T.C.M. (CCH) 684 (1999); Salina P'ship LP v. Comm'r., 80 T.C.M. (CCH) 686 (2000).

56. See, e.g., I.R.C. $\$ \S 332$ (c), 357(c), (d), 732(c), (f), 1259, 1260.

57. For descriptions of some current proposals, see Treasury White Paper, supra note 6, at 78-114; Dept. of Treasury, General Explanations of the Administration's Fiscal Year 2001 Revenue Proposals 122-38 (2000); U.S. J. Comm. on Tax'n, Study of Present-Law Penalty and Interest Provisions as Required by Section 3801 of the Internal Revenue Service Restructuring and Reform Act of 1998 (Including Provisions Relating to Corporate Tax Shelters), JCS-3-99, 232-59 (1999).

58. Cf. Cooper, supra note 2. 
efforts, and the game continues. ${ }^{59}$

The T.A. game is inefficient for several reasons. First, the basic activity that the government was trying to deter in the first place has not been curbed. Thus, if the government's objection to the activity was based on its inefficient consequences, that inefficiency has not been avoided. Secondly, the government's intervention, though ultimately unsuccessful, nevertheless causes the taxpayer to achieve its desired outcome in a less efficient manner. The taxpayer still accomplishes what the government objects to, but the taxpayer simply has to incur greater unproductive costs in reaching its desired end. Finally, the government has to incur administrative costs to discover what the taxpayer has done and to enforce the law or implement a new one.

Incremental change produces a second worry, one quite visible from the experience from the 1970's and 1980's. Even after the "war" is finally won, the incremental steps taken along the way, many of which having proven to be largely ineffective, remain as part of the law. It is like the detritus left on the battlefield after a major conflict. It has proven to be extremely difficult to clean out the underbrush of unnecessary tax laws once their time has passed. Instead, the underbrush remains as simply a lingering cost of the tax system and the earlier war, rules that must be navigated around by the well-advised and that stay behind to trip up the ill-advised. Arguably, two current examples of this underbrush emanating from the 1970's are the alternative minimum tax and the at risk rules.

By contrast, the experience since 1986 illustrates the potential advantage of taking a bold step to stem the undesired activity. Once the tipping point is reached, the T.A. game is over. ${ }^{60}$ Taxpayers stop trying to engage in the activity because the cost of doing so is too great, the reward is too small, or both. As a result, efficiency is gained not only because the inefficient activity itself is stopped, but also because the transactions costs to participate in or monitor and prevent the activity are avoided. The "bold step" may be quite complex, but if its consequence is to deter the targeted activity altogether, the net result may be a considerable simplification for the tax system and a reduction in costs. ${ }^{61}$

59. David Weisbach refers to this phenomenon as the "distortionary effect" of anti-tax avoidance rules, and David Schizer calls it the "planning option." See David A. Weisbach, An Economic Analysis of Anti-Tax Avoidance Laws, AM. L. \& ECON. REv. (forthcoming); David M. Schizer, Sticks and Snakes: Derivatives and Curtailing Aggressive Tax Planning, 73 S. CAL. L. REv. 1339, 1344, 1348-51 (2000); see also Daniel N. Shaviro, Economic Substance, Corporate Tax Shelters, and the Compaq Case, 88 TAx NotEs 221, 222-23 (2000) (describing how one possible response to anti-tax avoidance rules is for the taxpayer to assume greater risks and incur greater costs without any corresponding benefit to anyone).

60. As Prof. Weisbach describes, if the anti-tax avoidance rule is strong enough, the distortionary effect begins to decrease because the number of taxpayers who continue to try to engage in the avoidance activity declines. See Weisbach, supra note 59; see also Shaviro, supra note 59 , at 223 (objective of anti-tax avoidance rule is to deter the undesirable activity altogether).

61. See Stanley A. Koppelman, At-Risk and Passive Activity Limitations: Can Complexity Be Reduced?, 45 TAx L. REV. 97, 106 (1989); Jerome Kurtz, The Interest Deduction under Our Hybrid Tax System: Muddling Toward Accommodation, 50 TAx L. REv. 153, 
To be sure, incremental change offers the possible benefit of preventing the other type of error - adoption of a rule which overreaches and interferes with market transactions for no good purpose. An overbroad rule may also present greater equity objections than one that is too ineffectual. Nevertheless, if there is one lesson to be learned from the tax shelter experience of the 1970's and 1980's, it is the extent to which taxpayers are willing to play the T.A. game. Thus, if corporate tax shelters are as significant a problem as some now proclaim, policymakers should give serious consideration to bold responses. ${ }^{62}$

\section{B. What Stopped the Last Generation of Tax SHELTERS, AND WHY?}

It is difficult to know exactly what has caused tax shelter activity engaged in by individuals to recede since 1986. Non-tax economic conditions may be a factor, although this country has experienced a variety of conditions since then with no resurrection of the tax shelters. One or more of the tax changes leading up to and included as part of the 1986 Act certainly have been factors. It seems hardly a coincidence that shelters have been reduced since 1986 .

The 1986 Act contained many important tax changes, as did the 1982 and 1984 Acts immediately preceding it. It has been suggested that tax shelters were curbed as a result of the combination of the following major changes enacted in 1986: the lowering of income tax rates, which reduced the return from tax sheiters; the elimination of the capital gains preference; the lengthening of depreciation schedules; and enactment of section 469-the passive activity loss rules. ${ }^{63}$ But since 1986, income tax rates have risen, and the capital gains preference has returned, without any apparent resumption of the sheltering activity common prior to that time. Depreciation schedules have also been subject to change from time to time, although there have been no significant changes since 1986. New tax preferences have been enacted since 1986. One important constant throughout has been section 469. Although there is some difference of opinion, the consensus is that the passive activity loss rules have been a major factor, if not the single most critical factor, in the curbing of tax

223-34 (1995); Cecily W. Rock \& Daniel N. Shaviro, Passive Losses and the Improvement of Net Income Measurement, 7 VA. TAX REv, 1, 52 (1987); Daniel N. Shaviro, An Efficiency Analysis of Realization and Recognition Rules Under the Federal Income Tax, 48 TAX L. Rev. 1, 36 (1992). Some early commentary criticizing the complexity of the passive activity loss rules may have overlooked this simplifying potential of those rules. See Michael A. Oberst, The Passive Activity Provisions-A Tax Policy Blooper, 40 U. FLA. L. Rev. 641, 683 (1988); Robert J. Peroni, A Policy Critique of the Section 469 Passive Loss Rules, 62 S. CAL. L. Rev. 1, 95-102 (1988). A taxpayer with a large amount of earned income can avoid the complexities of complying with section 469 simply by curtailing his or her investments in limited partnerships and other vehicles generating passive losses. For a recent article again criticizing the complexity of section 469, see Mona L. Hymel, Tax Policy and the Passive Loss Rules: Is Anybody Listening?, 40 ARIz. L. Rev. 615, 641-43 (1998).

62. Cf. Calvin H. Johnson, Corporate Tax Shelters, 1997 and 1998, 81 TAX NoTES 1603, 1605-06 (1998).

63. See Petska, supra note 11 , at 8. 
shelter activity. ${ }^{64}$

Why has section 469 proven to be so effective? Certainly, the breadth and relative clarity of the rule are possible explanations. Although the meaning of the rule in any given case may be difficult to ascertain, its application to the mass of transactions that the government wished to deter has been plain enough.

Another possible explanation is that the rule is outcomes-oriented. In general, it is not concerned with which provision or provisions produce the particular tax consequences being claimed. It is not concerned with whether the taxpayer's activities are undertaken for valid business purposes or tax avoidance purposes, or with any other particular motive or intent. It is not concerned with how the amount of tax savings resulting from a transaction compares to its pre-tax economic return. Section 469 operates to prohibit or constrain certain outcomes, however they may be achieved and for whatever reason.

Section 469 has been much criticized in the literature on policy grounds. ${ }^{65}$ Although I disagree with certain of the criticisms, the point here is not to debate the merits of that particular rule. Section 469, for example, could not be easily adapted to apply to public corporations anyway. ${ }^{66}$ Rather, what is important is to observe the rule's positive effect on curbing the last generation of tax shelters, to identify the characteristics that have made it so effective, and to consider whether a rule with similar characteristics might be equally effective at curtailing corporate tax shelters. The next part discusses two possible section 469 clones.

64. See Calvin H. Johnson, Why Have Anti-Tax Shelter Legislation? A Response to Professor Zelenak, 67 Texas L. Rev. 591, 625 (1989); Calvin H. Johnson, What's a Tax Shelter?, 68 TAX Notes 879, 880 (1995); Koppelman, supra note 61, at 105; Kurtz, supra note 61, at 221-23; Rock \& Shaviro, supra note 61, at 3 . The principal view to the contrary is that section 469 was ultimately unnecessary; other changes would eventually have curbed tax shelters. See Hymel, supra note 61, at 622, 625; Lawrence Zelenak, When Good Preferences Go Bad: A Critical Analysis of the Anti-Tax Shelter Provisions of the Tax Reform Act of 1986, 67 Texas L. Rev. 499, 526-27 (1989). We may never know for sure which view is correct. Nevertheless, given the broad consensus regarding the undesirability of shelter activity, the huge strain it was placing on the tax system, and the evident success of section 469 in ending shelters after many failed efforts, there should be a heavy burden on those who would repeal section 469 on the theory that it is not needed.

It should be noted that section 469 merely defers losses; it does not disallow them altogether. See I.R.C. $\$ 469$ (b). Lengthening depreciation schedules has the same general effect. Thus, the fact that there seems to have been a reduction, and not a mere deferral, in the amount of losses from limited partnerships and LLCs since 1986 (see Figure 3) is further evidence of a change in the nature of the investments undertaken by those entities.

65. See Joseph Bankman, The Case Against Passive Investments: A Critical Appraisal of the Passive Loss Restrictions, 42 STAN. L. REv. 15 (1989); Hymel, supra note 61; Oberst, supra note 61; Peroni, supra note 61; Zelenak, supra note 64.

66. See Treasury White Paper, supra note 6, at 120. 


\section{POSSIBLE RESPONSES TO THE CORPORATE TAX SHELTER PROBLEM}

Does a solution exist that might have an effect on corporate tax shelters comparable to the one section 469 apparently has had on the last generation of shelters? This part briefly explores two possibilities.

\section{A. An “Anti-Abuse” Rule}

Consider first an "anti-abuse" rule of the type described by Professor Gunn: a rule that denies a tax result from a particular transaction if no sensible legislator would have approved of the result at the time the statute was drafted. ${ }^{67}$ The breadth of this rule is evident. It is also outcomesoriented. The focus of the rule is on the result achieved, not the manner in which the result is attained. The particular elements producing the claimed result, including the taxpayer's purpose or intent, are irrelevant except insofar as the elements shed light on the reaction of a sensible legislator to the overall result.

It is useful to compare an outcomes-oriented rule such as this with one that is means-oriented, such as codification of the business purpose doctrine. 68 An outcomes-oriented rule might well be preferred by tax practitioners over a means-oriented one. The reason is that the basic building blocks - the means - of both tax shelters and "real transactions"69 may be quite similar, distinguished only by relatively subtle nuances. Thus, a means-oriented rule, particularly if codified in the statute rather than left to a case-by-case determination by the courts, may be used against too broad a scope of transactions. ${ }^{70}$

But how clear is an anti-abuse rule of the type mentioned above? Peter Canellos asserts that the distinction between a tax shelter and an aggressively structured real transaction is actually quite easy to identify if

67. Gunn, supra note 4, at 160 . Peter Canellos offers a similar definition: an abusive transaction is one which produces "a gross departure from sensible economic results and the fundamental tax principles underlying the Code." Canellos, supra note 2, at 69. David Hariton describes the same type of rule as being the "essence of the economic substance doctrine." See David P. Hariton, Sorting Out the Tangle of Economic Substance, 52 TAX LAw. 235, 246 (1999).

68. Under the business purpose doctrine, the taxpayer must have a reason for undertaking a transaction other than the avoidance of federal taxes. See Treasury White Paper, supra note 6 , at 55 . There are several versions of the economic substance doctrine; some of these are means-oriented and some might be considered outcomes-oriented. Cf. id. at 56; Hariton, supra note 67, at 241, 246; Lee Sheppard, Economic Substance Abuse, 89 TAX Notes 1095, 1095 (2000).

69. See Canellos, supra note 2, at 55-57.

70. See id.; Mark P. Gergen, The Common Knowledge of Tax Abuse, 54 SMU L. REv. 131, 136 (2001) ("[t]he standards of tax motive and economic substance cast a pall over some day-to-day tax planning"); David P. Hariton, Tax Benefits, Tax Administration, and Legislative Intent, 53 TAX Law. 579, 583 (2000) (explaining why one must look beyond the question of whether the element of "economic substance" is present to whether the result is abusive); N.Y. State Bar Ass'n Tax Section, Treasury's Proposal to Codify the Economic Substance Doctrine, 88 TAX Notes 937, 944-45 (2000). 
the totality of the transaction is taken into account. ${ }^{71}$ Almost in the next breath, however, he describes the "significant differences between classic shelter activity and financial product innovation"-with the latter transactions apparently deserving of respect by the tax authorities-in the following terms: "the tax benefits sought in financial products do not generally involve abuse of the tax system to the same degree as true shelters. Gross sheltering of unrelated income is typically not involved, and the deductions generated substantially comport with the investor's return."72

The need for so many qualifiers suggests that the distinction between abusive and non-abusive transactions may be more difficult than $\mathrm{Mr}$. Canellos lets on. At another point, he explains that the step-down preferred transaction was properly curtailed by the government because even though the transaction "probably worked under then-existing rules[, it] was too good to be true."73 Yet Professor Gunn explains that some "very-favorable tax results, results that may seem too good to be true, are sometimes required by the language and purpose of particular statutory provisions" and are not, therefore, negated by the partnership anti-abuse regulations. ${ }^{74}$

The potential lack of clarity of an anti-abuse rule can be illustrated by the facts of Compaq Computer Corp. v. Commissioner. ${ }^{75}$ In that case, the U.S. corporate taxpayer purchased and then immediately sold (to the same person from whom it made the purchase) the equivalent of some portfolio shares in a Dutch corporation. The sale price was for about $\$ 19$ million less than the purchase price. During the extremely brief period of ownership (one hour, at best), however, the taxpayer became entitled to receive a dividend from the Dutch company. The gross amount of the dividend was about $\$ 22$ million but there was a Dutch income tax withheld from the dividend of about $\$ 3$ million. Thus, the net amount of the dividend actually paid to the taxpayer was about $\$ 19$ million. The taxpayer carried out virtually the entire transaction through its margin account and incurred transactions costs of about $\$ 1.5$ million consisting of a $\$ 1$ million fee to the promoter and $\$ 500,000$ in interest to the lending institution.

The pre-tax result to the taxpayer was about a $\$ 1.5$ million loss: the $\$ 19$ million net dividend almost exactly offset the $\$ 19$ million loss on the sale of the stock, but the taxpayer still incurred the $\$ 1.5$ million in costs. According to the position taken by the taxpayer, however, the transaction

71. See Canellos, supra note 2, at 51 ("experienced tax professionals can usually readily distinguish tax shelters from real transactions"). Professor Gergen says something similar: "Good tax lawyers know when they are pushing hard at the edge of the envelope." Gergen, supra note 70, at 136.

72. See Canellos, supra note 2 , at 55 (emphasis added).

73. Id. at 54 .

74. Gunn, supra note 4 , at 174 (emphasis added).

75. 113 T.C. 214 (1999). 
produced roughly a $\$ 1$ million after-tax gain, computed as follows: ${ }^{76}$

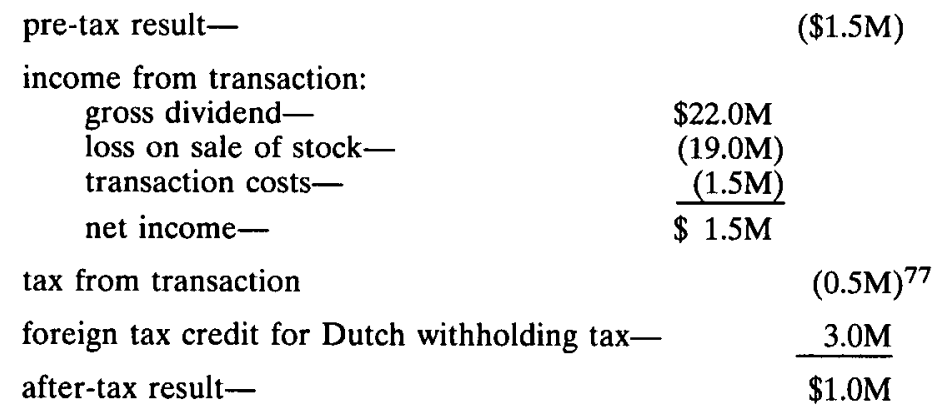

The Tax Court denied the taxpayer's claim for the foreign tax credit and also assessed negligence penalties against the taxpayer. ${ }^{78}$

Many people view Compaq as an example of the current crop of corporate tax shelters. ${ }^{79}$ Certainly, the court found little merit in the taxpayer's claim. But would the taxpayer's position be rejected by the anti-abuse rule described earlier? At one level, the answer to that question seems easy. The taxpayer incurred almost no risk (ownership of the stock was for at most one hour, and the purchase and resale were arranged from the start) and committed almost no capital (the purchase was financed by borrowed funds, and the borrowing cost is included in the pre-tax and after-tax results), yet according to the taxpayer, it was entitled to convert a $\$ 1.5$ million pre-tax loss into a $\$ 1.0$ million after-tax gain. One might fairly assume that a sensible legislator would think this result to be too good to be true, and therefore impermissible.

Yet on further reflection, the answer may not be so easy after all. What made the transaction work was Compaq's ability to purchase stock whose price had not capitalized the value of the foreign tax credit. The stock price fell by only $\$ 19$ million, the net after-tax value of the dividend, without any consideration for the creditable nature of the Dutch tax. This was a perfectly reasonable market response for Dutch shareholders not entitled to any foreign tax credit. But it was a potential boon for shareholders like Compaq which were entitled to one.

In other words, Compaq tried to take advantage of a market situation not unlike that of a top-bracket taxpayer purchasing tax-exempt bonds

76. These figures assume that both the capital loss and the $\$ 1.5$ million in costs were immediately deductible. The taxpayer had a sizable capital gain that was sheltered by the capital loss. If the transaction costs were not immediately deductible, the after-tax gain would be less than what is shown in the text but the point would remain the same.

77. For computational ease, I have assumed the taxpayer paid taxes equal to one-third of its net income from the transaction.

78. 113 T.C. at 219. For taxable years subsequent to the ones in issue in Compaq, section $901(\mathrm{k})$ would bar the taxpayer's entitlement to a foreign tax credit in the circumstances of that case.

79. See, e.g., Elizabeth Magin, From Shelters to Hookers, 1999 Was a Lively Year in the Courts, 86 TAX Notes 22, 22 (2000); Shaviro, supra note 59, at 226-28; Lee Sheppard, Courts Combat Corporate Tax Shelters, 85 TAX Notes 137 (1999). 
whose price and yield have not fully capitalized the tax benefit to such taxpayer. ${ }^{80}$ Would such a purchase be violative of the anti-abuse rule?

To muddy the question further, suppose some of the worst smelling aspects of the Compaq transaction were eliminated. Suppose Compaq purchased on the market some shares in a Dutch utility company, or perhaps some high-quality Dutch preferred stock, and held the shares for a few months before selling them, again on the market. Suppose, as expected, the additional period of ownership did not result in any significant economic risk being borne by Compaq, and the pricing of the shares and all other facts turned out to be the same as in the actual case. Should Compaq be permitted to claim the foreign tax credit in this situation despite the existence of an anti-abuse rule? Wouldn't the "too good to be true" aspect of the transaction still be present? ${ }^{81}$

The lack of clarity of an anti-abuse rule weakens its utility as a weapon against corporate tax shelters. Aside from the problem of possibly applying to erroneous cases, an unclear rule may actually lead to more aggressive tax planning by taxpayers. This is because of the comparative resource advantage that taxpayers - particularly the large corporate taxpayers participating in corporate tax shelter activity-have over the government. Thus, taxpayers may reasonably expect to gain more from the uncertainty than the government. ${ }^{82}$

Finally, an unclear rule lacks transparency. Taxpayers may reasonably object to whether the rule is applied in a sufficiently even-handed manner. ${ }^{83}$ As Professor Cooper notes, this is a common complaint of statu-

80. See Shaviro, supra note 59 , at 225 . For example, a taxpayer in the $40 \%$ marginal tax bracket who purchases a tax-exempt state or local bond which has only capitalized the tax benefits obtained by a taxpayer in the $30 \%$ bracket captures a portion of the federal subsidy intended for the state or local jurisdiction.

81. David Hariton argues that this revised transaction should not be considered abusive because the taxpayer is crediting foreign taxes under circumstances where Congress intended the credits to be available. In contrast, he asserts that where the taxpayer's ownership is too fleeting (as in the actual case), the foreign tax credit should be unavailable because Congress did not intend credits in that situation. See Hariton, supra note 70 , at 609-12. But should the foreign tax credit be denied if the taxpayer's ownership is fleeting yet the stock price does capitalize the value of the credit? What would be abusive in that situation?

82. See Weisbach, supra note 59; Edward D. Kleinbard, Corporate Tax Shelters and Corporate Tax Management, 51 TAX ExEc. 235, 242 (1999).

83. See Kleinbard, supra note 82 , at 235 ("an emphasis on standards would significantly undermine our rule-based system by interjecting an unacceptably high degree of arbitrariness into the process, which would ultimately corrode the most important aspect of our corporate tax system - the sense of its underlying fairness"); Kenneth W. Gideon, Assessing the Income Tax: Transparency, Simplicity, Fairness, 81 TAX NotEs 999, 1001 (1998) ("[a]ntiabuse rules transfer [the] decision making process [of whether a tax benefit will be allowed] from the open and uniform arena of rulemaking to the uncertainties of the audit process and virtually assure that the results will vary from taxpayer to taxpayer."). Mr. Canellos asserts that there is a sharp distinction between the "tax bar" and the "tax shelter bar" and that "[i]t is inconceivable that a practitioner who specialized in tax shelters would ever reach a position of responsibility in [the leading tax bar] organizations." Canellos, supra note 2, at 56 . His position suggests a possible safe harbor: a client represented by a past or current tax bar leader would have the tax consequences of the client's transactions 
tory general anti-avoidance rules (GAARs) ${ }^{84}$ But the standard response to this criticism-reassurance that the GAAR will rarely be used and will only apply to the most blatant and contrived cases ${ }^{85}$-is of no help in our search for a section 469 clone. If the anti-abuse rule is so watered down that it becomes, in Prof. Cooper's words, "just another part of the tax landscape which practitioners and the judiciary [must] negotiate," 86 then, sadly, enactment of the rule will have been just another move in the T.A. game. ${ }^{87}$

\section{B. Taxing Public Corporations on Their Adjusted BOOK INCOME}

Consider the following rule: suppose public corporations are taxed each year on the amount of income they report for financial accounting purposes, as adjusted by tax rules authorizing specific deviations from a book income tax base. Thus, the starting tax base for public corporations would be their reported book income, but specific provisions could modify that result. If, for example, Congress deemed it desirable to allow different depreciation rules for book and tax purposes, ${ }^{88}$ different consequences from the exercise of nonqualified stock options, ${ }^{89}$ different treatment of foreign income, ${ }^{90}$ or any other book-tax differences, Congress

insulated from a challenge based on the anti-abuse rule. If nothing else, such a rule would certainly spur interest and participation in bar activities!

84. See Cooper, supra note 1, at 114; see also Gergen, supra note 70, at 131-32.

85. See Cooper, supra note 1 , at 93.

86. Id. at 85 .

87. The experience with the partnership anti-abuse regulations seems to have followed exactly this pattern. Originally proposed with some real bite, they have become so watered down in their final version that they are, in some respects, "quite pro-taxpayer." Gunn, supra note 4, at 174. See T.D. 8588, 1995-1 C.B. 109, 110-11 for a description of the changes made to the proposed version of the regulations, including the addition of a number of examples illustrating transactions protected from challenge. For the proposed version of the regulations, see PS-27-94, 1994-1 C.B. 832. Professor Gunn identifies several transactions which are treated by the regulations as nonabusive even though the taxpayers obtain "significant tax benefits ... without good business reasons for doing so." Gunn, supra note 4 , at 167 . He concludes that "[t]he antiabuse regulations seem destined to play no part in the affairs of most partnerships." Id. at 173. See also Cooper, supra note 1, at 127 (explaining how infrequently the GAAR has been applied in Australia and Canada and how inconsequential it has sometimes proven to be).

88. Corporations are currently permitted to use different depreciation methods for these two purposes. See Handiook of Accounting AND Auditing, 1999-2 edition, C4.02[2][e] (Frank C. Minter et al., eds. 1999-2 ed.) [hereinafter Accounting HANDBOOK].

89. In general, the corporate issuer of a nonqualified stock option is entitled to deduct for tax purposes the difference between the value of the stock at the time of the option's exercise and the option's exercise price. See I.R.C. $\S 83(\mathrm{~h})$. In contrast, corporations are generally not required to reduce their earnings for financial accounting purposes by this difference as long as the exercise price of the option is at least equal to the value of the stock at the time the option is granted. See Accounting for Stock-Based Compensation, SFAS No. 123; Accounting for Stock Issued to Employees, APB No. 25.

90. The consolidation of foreign subsidiaries with their domestic parents are currently treated differently for tax and accounting purposes. In general, a foreign subsidiary may not be included in the consolidated income tax return of a U.S. parent. See I.R.C. $\S 1504(b)(4)$. In contrast, the financial results of a foreign subsidiary are generally in- 
would simply have to enact the particular adjustment. In the absence of any adjustment, however, a public corporation would pay tax on its book income. The potential advantage of shifting to a book income tax base with adjustments is to improve the transparency of the tax base: intended deviations from book income, but only intended deviations, would be permitted in calculating taxable income. ${ }^{91}$ A complete discussion of this possible change in the law will have to await a future article, but some preliminary thoughts are outlined below.

\section{Effect on Corporate Tax Shelters}

According to the Treasury Department, a principal characteristic of corporate tax shelters is inconsistent treatment for financial accounting and tax purposes of the items resulting from the shelter. A shelter might be designed, for example, to produce a tax loss without any corresponding book loss. Indeed, public corporations generally do not find appealing tax shelters which result in consistent book-tax treatment because of the adverse effect of such shelters on their reported earnings. Although there is limited disclosure required of book-tax disparities for both tax and accounting purposes, the great number of differences permits much shelter activity to remain hidden from view. 92

The entire class of shelters with this common characteristic would end if corporations were taxed on their adjusted book income. ${ }^{93}$ By linking taxable income to book income, Congress would eliminate the ability of corporations to explore unintended and undesirable deviations between the two measures. Congress would gain greater control over the corporate tax base; intended book-tax disparities could be specifically authorized but unintended ones would essentially end. ${ }^{94}$ The rule would have similar characteristics to section 469: it would be broad, reasonably clear, and very outcomes-oriented, with tax consequences literally being determined by the "bottom line." Tax results would not depend upon taxpayer intent, motive, or similar factors.

cluded in the results of its U.S. parent so long as the parent owns over 50 percent of the subsidiary. See ACCOUNTING HANDBOOK, supra note 88, at C13.01[1].

91. This procedure would also make plain Congress's control over the definition of the corporate income tax base. $C f$. Treasury White Paper, supra note 6, at 119 (expressing concern that a book income adjustment would result in Congress ceding some of its authority to other bodies such as the AICPA, FASB, and the SEC).

92. See id. at 14-15; Joseph Bankman, The New Market in Corporate Tax Shelters, 83 TAX Notes 1775, 1785-86 (1999).

93. The rule may not affect, however, Compaq-type shelters involving the possible inappropriate claiming of credits. Cf. James B. Mackie III, The Puzzling Comeback of the Corporate Income Tax: Why Have Tax Payments Increased While the Average Tax Rate Has Declined During the 1990s?, 1999 ProceEdINGS OF THE NAT'L TAX Assn. (forthcoming) (questions whether book-tax differences of corporate tax shelters is reason for decline in corporate average tax rate).

94. The failure to distinguish between intended and unintended tax benefits is a common criticism of the passive activity loss rules. See, e.g., Koppelman, supra note 61, at 103; Zelenak, supra note 64, at 520-24. It is also a frequently expressed concern regarding current anti-corporate tax shelter proposals. See Canellos, supra note 2; Hariton, supra note 67 , at 273; Hariton, supra note 70 , at 613 . 


\section{Tax Policy Considerations}

Aside from its possible impact on corporate tax shelters, is the rule consistent with sound tax policy? The rule requires public corporations to be taxed more closely on their economic income, if one assumes that income reported for financial accounting purposes is a closer approximation of that than taxable income..$^{95}$ But how does the rule compare to current law from the standpoint of equity, efficiency, and administrative simplicity?

It is hard to assess the equity implications of the rule because they depend upon identifying who bears the burden of the corporate tax. For example, if corporation $\mathrm{X}$ pays more tax under the proposal than under current law, it is difficult to determine whether that result is equitable without knowing who bears the burden of X's tax liability.

An efficiency objection arises if the rule is not even-handed in its application. Because corporations to some extent can manage the amount of financial earnings they report in a given year, a tax base based on book income would seem to violate a neutrality objective. Such a rule could allow similarly situated corporations to pay different amounts of tax, depending upon the earnings they decide to report in a given year.

On the other hand, to the extent reported earnings make a difference to investors-obviously, an uncertain assumption-financial accounting policy should promote uniform treatment of corporations. Thus, although the amount of earnings are to some degree manipulable by corporate management, similarly situated corporations may have an equal opportunity to engage in such manipulations. If this is true, then part of the efficiency objection should disappear. A corporation's choice regarding how it balances its desire to report high financial earnings and low taxable income would be similar to other choices it faces in operating its business. ${ }^{96}$ Tax rates can be adjusted to raise the desired amount of revenue based on the amount of earnings reported.

To be sure, certain corporations, particularly those in different industries, would no doubt have differing abilities to engage in earnings management. Thus, a tax based on adjusted book income would cause some distortion and inefficiency. What is unknown is whether this distortion would be greater than that of current law, which also taxes some corporations in different industries in different ways. ${ }^{97}$

95. See U.S. J. Comm. on Tax'n, General Explanation of the Tax Reform Act of 1986, JCS-10-87, 434 (Comm. Print 1987) (reason for inclusion of book income tax preference in corporate minimum tax was to tax corporate economic income and to restore public confidence in the fairness of the tax system).

96. This position is consistent with Professor Gergen's assertion that "[f]rom an allocative perspective the evil in exploitative tax planning lies more in the effort spent in playing the game than in the outcome." Gergen, supra note 70 , at 145 . If corporations have an equal opportunity to engage in tax shelter planning, then the principal efficiency objection of shelters may be the transactions costs to the taxpayers and the IRS.

97. For example, see I.R.C. subchapters $\mathrm{H}$ (special tax rules for banking institutions), I (natural resources), and L (insurance companies). 
Moreover, balanced against that inefficiency would be the potential simplification gain from a tax on adjusted book income. The planning, compliance and administration costs of the current corporate tax are quite high. ${ }^{98}$ Tying taxable income to the amount of book income, even with a number of authorized adjustments, could be a major simplification and result in a reduction in costs. ${ }^{99}$

\section{Accounting Policy Considerations}

A tax based on adjusted book income would motivate some corporations to report lower earnings simply to reduce their tax bill. Thus, the tax might have the adverse effect of degrading the quality of financial reporting. ${ }^{100}$ On the other hand, financial reporting is already degraded to some extent. Under current law, corporations obtain two different bites at the apple: they take advantage of ambiguities in the financial accounting rules to puff up the amount of their financial earnings, and take advantage of similar ambiguities in the tax rules to understate the amount of their taxable earnings. Further, they lobby Congress and the relevant administrative agencies to maintain and enlarge the ambiguities in each set of rules. Linking tax consequences more closely to book consequences eliminates one of those opportunities. Although adoption of the tax rule discussed here may ultimately result in lower reported earnings, it may be that such reports will represent more reliable assessments of the financial situations of the corporations than are currently provided.

\section{Limitation to Public Companies}

The tax on adjusted book income would only apply to public companies because of the potential discipline imposed by public markets on the amount of corporate earnings reported. But there is another reason to

98. See U.S. GAO, Tax System Burden: Tax Compliance Burden Faced by Business Taxpayers (1994), GAO/T-GGD-95-42; David R. Seltzer, Federal Income Tax Compliance Costs: A Case Study of Hewlett-Packard Company, 50 NAT'L TAX J. 487 (1997); Joel B. Slemrod \& Marsha Blumenthal, The Income Tax Compliance Cost of Big Business, 24 PuB. FIN. Q. 411 (1996).

99. See Seltzer, supra note 98 , at 492 ("strong links between the company's tax reporting systems and its general ledger are an important factor in mitigating the overall compliance burden. Conversely, when those links are absent, compliance costs increase markedly."); compare Thomas M. Porcano et al., Alignment of Taxable Income with Accounting Profit, 10 Austl. TAX F. 475, 500-01 (1993) (questioning whether system would be simpler). The Treasury concluded that a similar proposal would add significant complexity. Treasury's proposal, however, would use book income as a floor in the computation of a corporation's taxable income, similar to the book income adjustment in effect for 1987 through 1989 for purposes of the corporate minimum tax. Thus, Treasury's proposal would add an additional requirement to all of the complexity of current law. In contrast, the proposal described in the text would substitute a new system for much of current law's complexity. See Treasury White Paper, supra note 6, at 116-19.

100. See Calvin Johnson, GAAP Tax, 83 TAx Notes 425, 427 (1999). However, a recent study of the 1987-89 period, when corporate taxes were linked to reported book income through application of the corporate minimum tax, questions the degree of earnings management undertaken by corporations in response to that law. See Won W. Choi et al., Potential Errors in Detection of Earnings Management: Reexamining Studies Investigating the $A M T$ of 1986 (2000) (unpublished paper). 
limit the proposal to public corporations-they probably represent the heart of the corporate tax shelter problem. According to the Treasury Department, the principal benefit of corporate tax shelters is the saving in corporate income taxes. ${ }^{101}$ Yet the very largest corporations, which are disproportionately public companies, pay the bulk of the corporate tax and therefore are likely to be the major players in corporate shelters. ${ }^{102}$ Private corporations taxed under subchapter $\mathrm{C}$ have many opportunities unavailable to public corporations to reduce or eliminate their corporate income by paying out their earnings in tax-deductible ways. ${ }^{103}$

Moreover, under the check-the-box entity classification rules, new private ventures have an enhanced ability to avoid the corporate tax altogether in the future. This option is unavailable to public firms. ${ }^{104}$ Thus, the existing difference between public and private companies for tax purposes affords an excellent opportunity to consider reforms that take advantage of the unique features of the firms in each sector to determine the simplest, most efficient way of raising taxes from that sector. ${ }^{105}$

\section{Integration}

The proposed rule redefines the corporate tax base. Most major corporate integration proposals retain some form of corporate tax, with the shareholder tax being reduced or eliminated in some way. ${ }^{106}$ Thus, the proposal could be implemented consistently with almost any integration objective.

101. See Treasury White Paper, supra note 6, at 25.

102. In 1997, there were 9,017 corporations with $\$ 250$ million or more in assets, the largest asset category segregated by the IRS, out of a total of 4.71 million corporations and 2.26 million non-subchapter $\mathrm{S}$ corporations. Although these largest corporations represented only approximately 0.4 percent of all non-subchapter $\mathrm{S}$ corporations, they paid $\$ 143.5$ billion in corporate tax, or 77.9 percent of the total corporate tax of $\$ 184.2$ billion that year. See Internal Revenue Service, Statistics of Income Division, Cor poration SourCE Book 1997, Publ'n 1053 at 9, 481 (2000). See also John W. Lee, A Populist Perspective of the Business Tax Entities Universe: "Hey the Stars Might Lie But the Numbers Never Do", 78 TeXAs L. Rev. 885, 903-08 (2000). For data indicating that public corporations fall disproportionately among the higher asset-size categories, see GEORGE K. YIN \& David J. Shakow, American Law Institute, Federal Income Tax Project: TaxaTION OF PRIVATE Business ENTERPRISES-RePORTERS' STUDY, 150-51 (1999) [hereinafter ALI REPORTERs' STUDY]; See also Bankman, supra note 92, at 1784 ("majority of tax shelters are purchased by corporations with diffuse ownership interests").

103. See Lee, supra note 102, at 918.

104. See I.R.C. \& 7704(a); Treas. Reg. $\$ 301.7701-2(b)(7)$ (public firm ineligible to make entity classification election).

105. See ALI Reporters' Study, supra note 102, for a discussion of how the taxation of private firms might be reformed.

106. See, e.g., U.S. DePt. of Treasury, Integration of the Individual and Corporate Tax Systems: Taxing Business Income OnCe (1992); American Law Institute, Federal Income Tax Project: Integration of the Individual and Corporate InCOME TAXes-Reporters' Study of Corporate TaX Integration (1993). 


\section{Cross-Border Considerations}

For U.S. corporations with foreign subsidiaries, the principal question will be how to reconcile the different consolidation standards that currently exist for tax and accounting purposes. The tax rules could be conformed to the accounting rules, in which case U.S. corporations would be taxed currently on the earnings of their foreign subsidiaries. ${ }^{107}$ Alternatively, a specific book-tax deviation could be enacted to continue the current U.S. tax treatment of those earnings.

Taxing foreign corporations with U.S. operations would be a little trickier. If the domestic operations were carried out through a separate subsidiary, the subsidiary could be required to prepare financial statements in accordance with U.S. financial accounting rules and report U.S. taxable income accordingly. The same requirement might be imposed even if the domestic operations were carried out through a U.S. branch. Alternatively, the foreign parent corporation might be required to report its earnings using international accounting standards, with the U.S. portion of those earnings then being taxed by the U.S.

\section{Summary}

Much has been written about the evolution of the corporate tax department from being a mere part of the overhead to a profit center. ${ }^{108}$ In truth, well-run corporations have long viewed taxes as a cost which, within limits, should be minimized. Sharp tax accountants and lawyers have presumably always been valued corporate employees and advisors. What may be different, perhaps, is the extent to which corporations are now willing to go to achieve their tax minimization objectives. Fueled by rumors of a competitor's latest tax saving plan that aggressively exploits one of the many complex and possibly irrational features of the corporate tax law, corporate officers apparently feel more and more compelled to engage in the T.A. game. ${ }^{109}$ An adjusted book income tax may both simplify the law, thereby reducing the number of tax law opportunities that can be exploited, and make the remaining competition more open. Corporate executives would be able to have confidence that a competitor's reporting of higher earnings is not simply financed by some tax avoidance scheme not availed of by their own company; rather, the earnings would be accompanied by a tax bill commensurate to the amount reported.

107. Some commentators support this outcome, quite apart from any consideration of corporate tax shelters or a possible adjusted book income tax. See Robert J. Peroni et al., Getting Serious about Curtailing Deferral of U.S. Tax on Foreign Source Income, 52 SMU L. REv. 455 (1999).

108. See Treasury White Paper, supra note 6, at 28-29; Bankman, supra note 92, at 1784.

109. See Bankman, supra note 92 ; Kleinbard, supra note 82 , at 235 ("[c]orporate tax shelters ... [are] a demand-driven phenomenon ... [which] trend is irreversible and will only intensify as corporate managerial arts become more sophisticated"). 


\section{CONCLUSION}

What should be done about corporate tax shelters? The first thing to do is to evaluate carefully the scope and severity of the problem. Despite mounting anecdotal evidence of a problem, the evidence is still only anecdotal. We need to understand better the exact nature of the problem and how widespread it is.

Assuming that the problem is as serious as some claim, Congress should give meaningful consideration to a bold response. The history of the last major wave of tax shelter activity in this country lends ample evidence to how counterproductive incremental reform can be. Small steps may lead simply to more avoidance behavior and greater inefficiency, and may leave behind much harm to the tax system even after the fight against tax shelters is over.

What type of bold response would be appropriate? This article has suggested searching for a solution with the same characteristics as section 469-a broad, reasonably clear, outcomes-oriented rule that is unaffected by taxpayer purpose or intent, or the other elements making up the taxpayer's transaction. One possible solution is enactment of an "antiabuse" rule which denies a particular tax result if no sensible legislator would have approved of the result at the time the statute was drafted. The uncertainty of such a rule, however, would likely undermine its ability to be an effective deterrent to corporate tax shelters. The other possible solution explored in this article, which deserves further consideration, is to tax public corporations on their income reported for financial accounting purposes, as adjusted by tax rules authorizing specific deviations from that base. This solution should eliminate an entire class of shelter transactions. It may also greatly simplify the law and provide much needed transparency to the process of determining corporate income tax liabilities. 


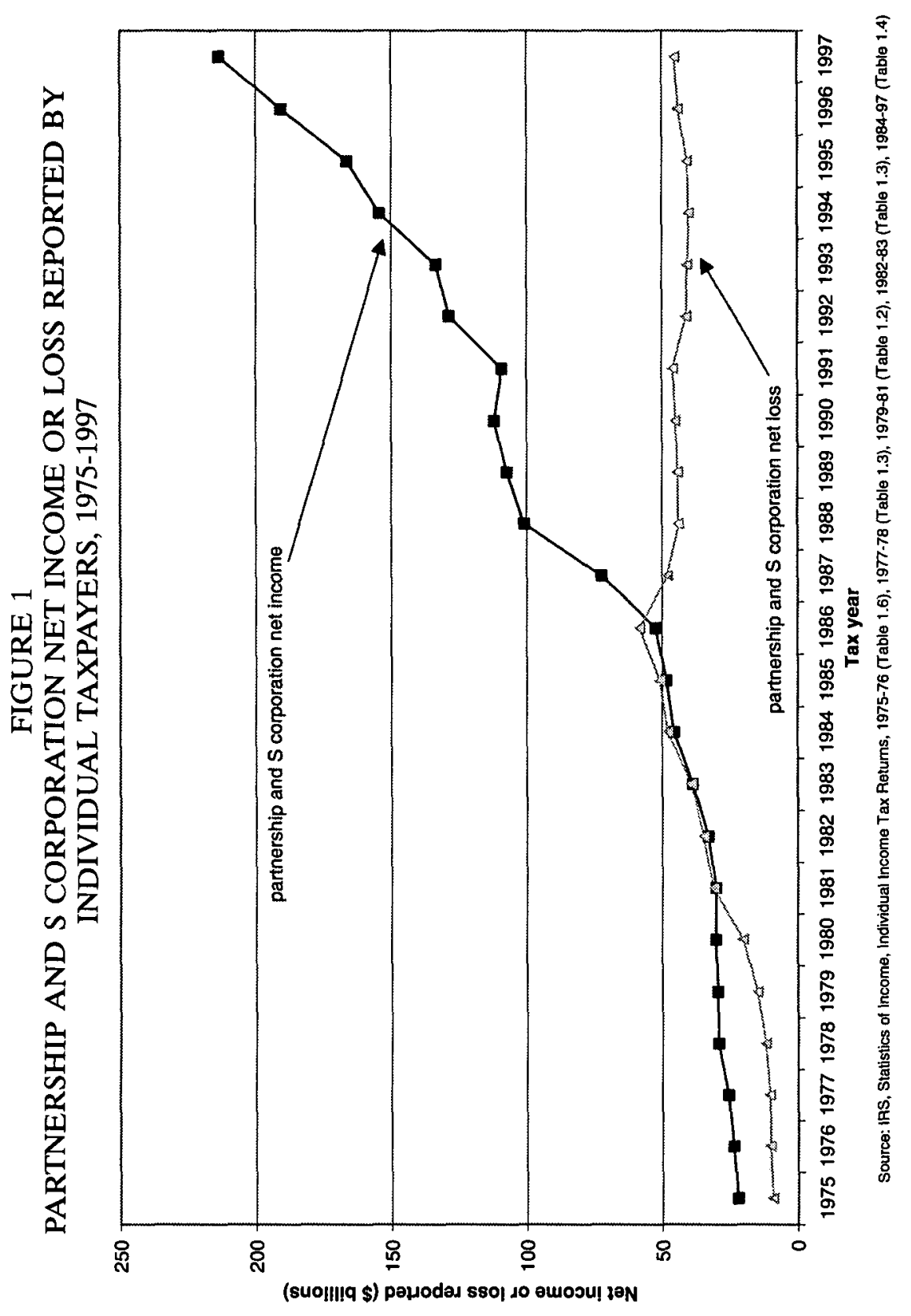




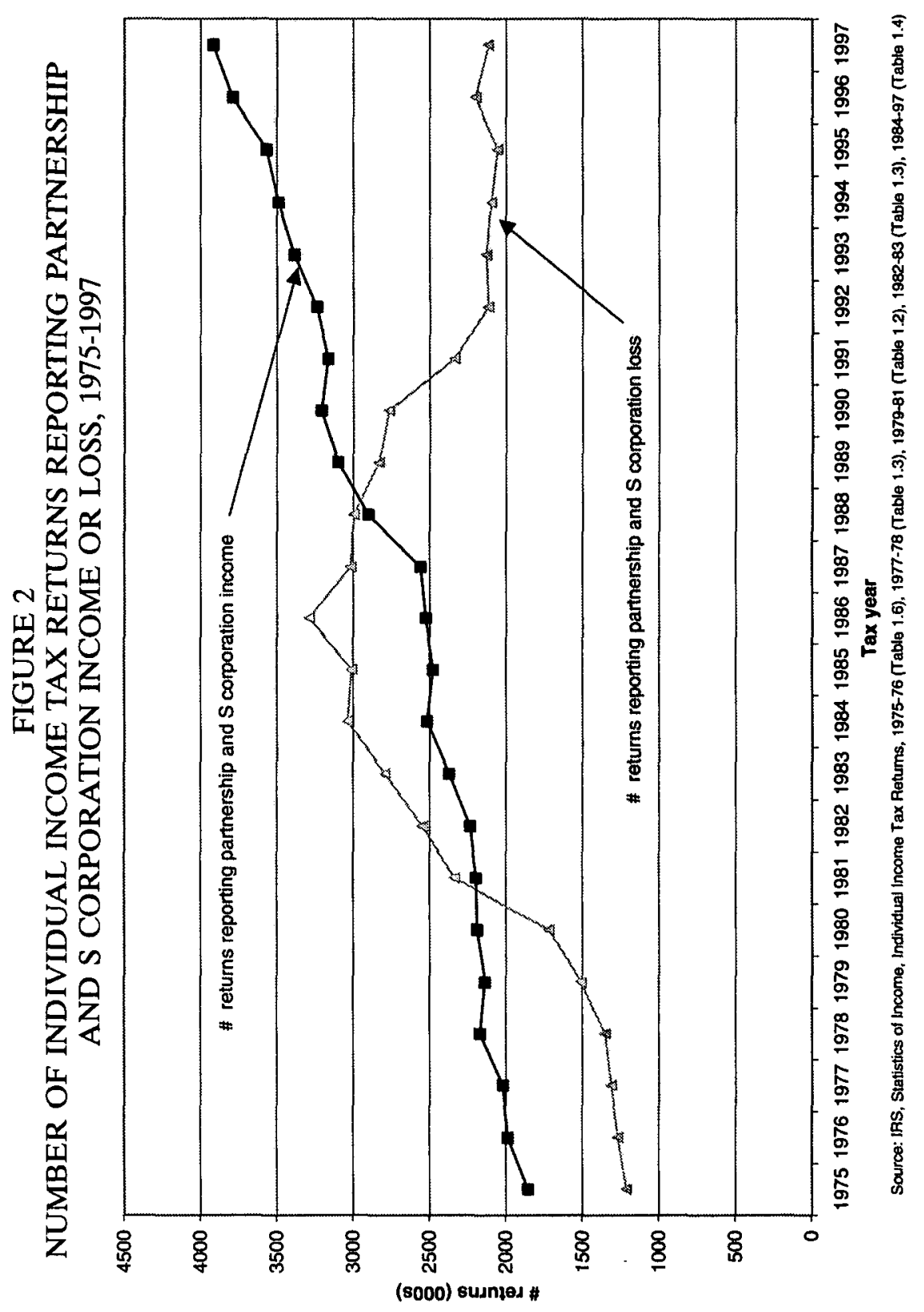




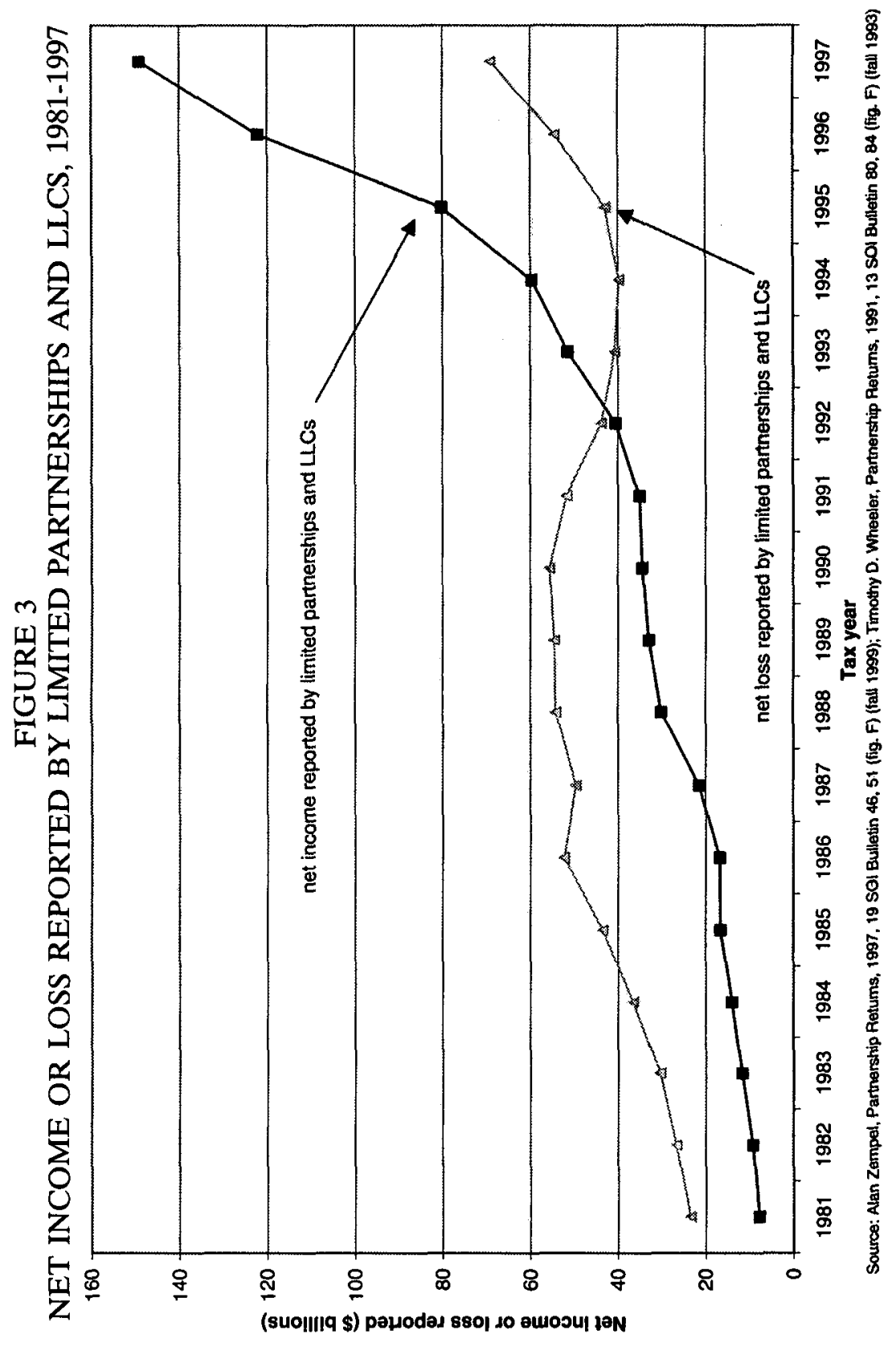


[Vol. 54

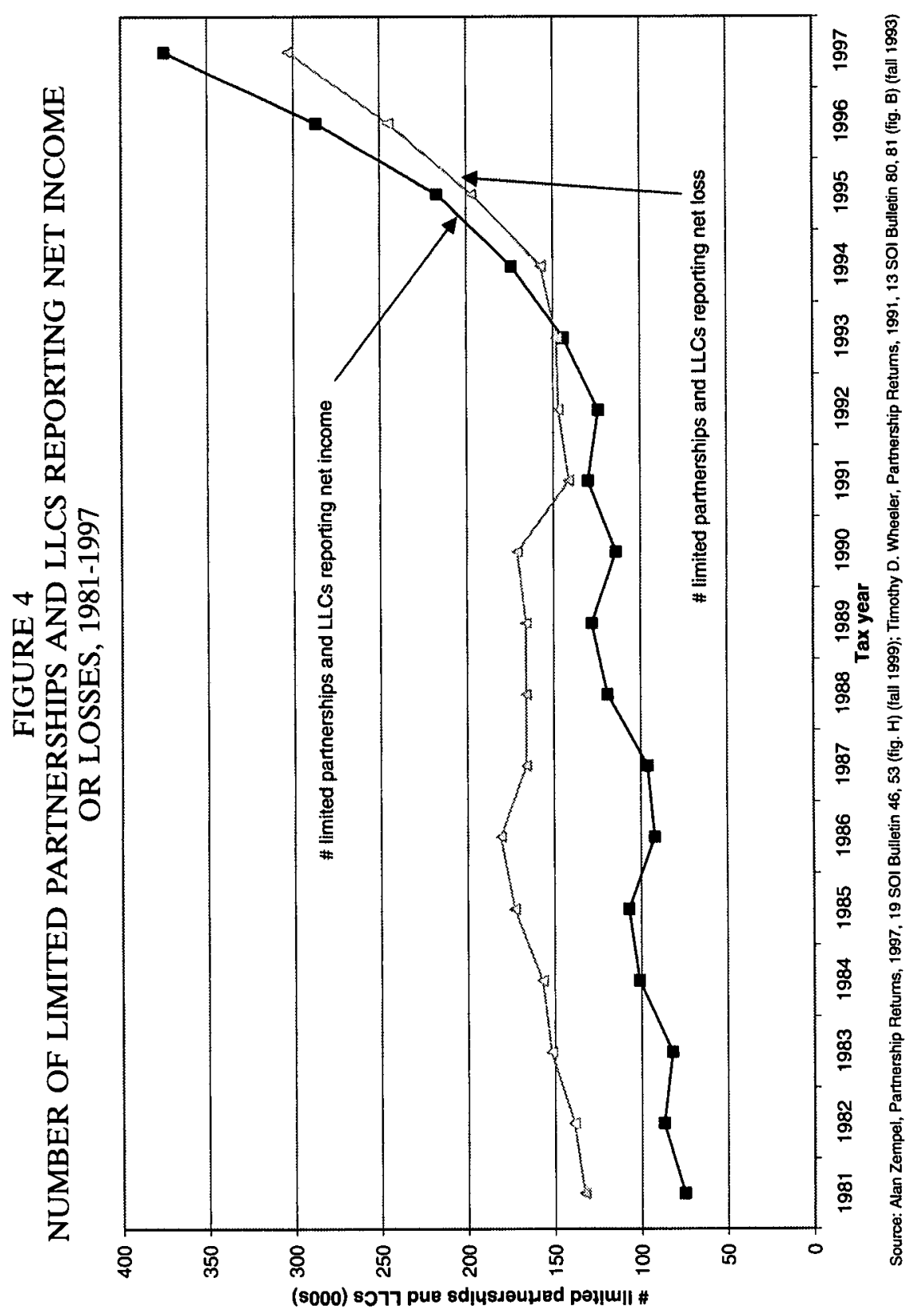




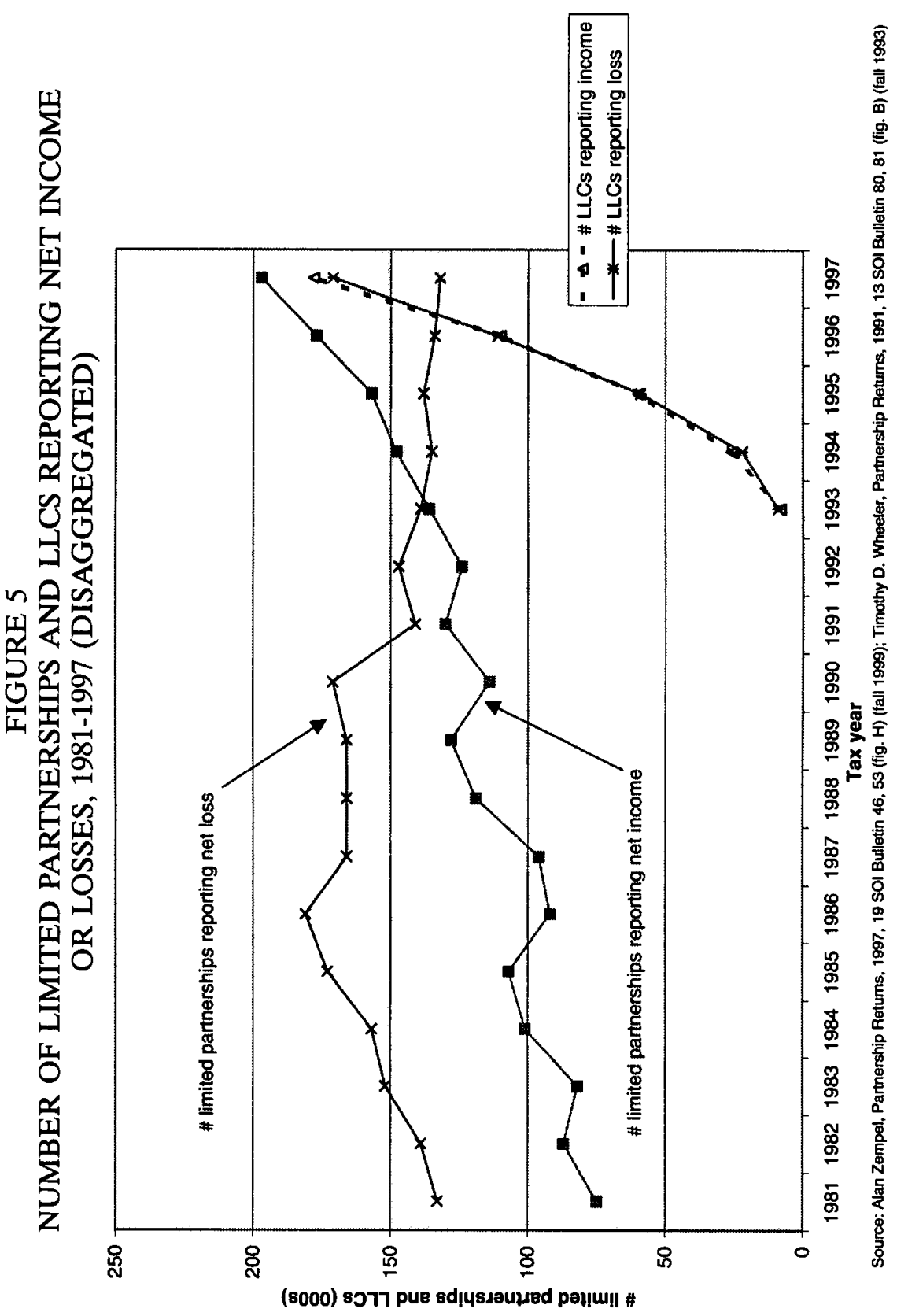




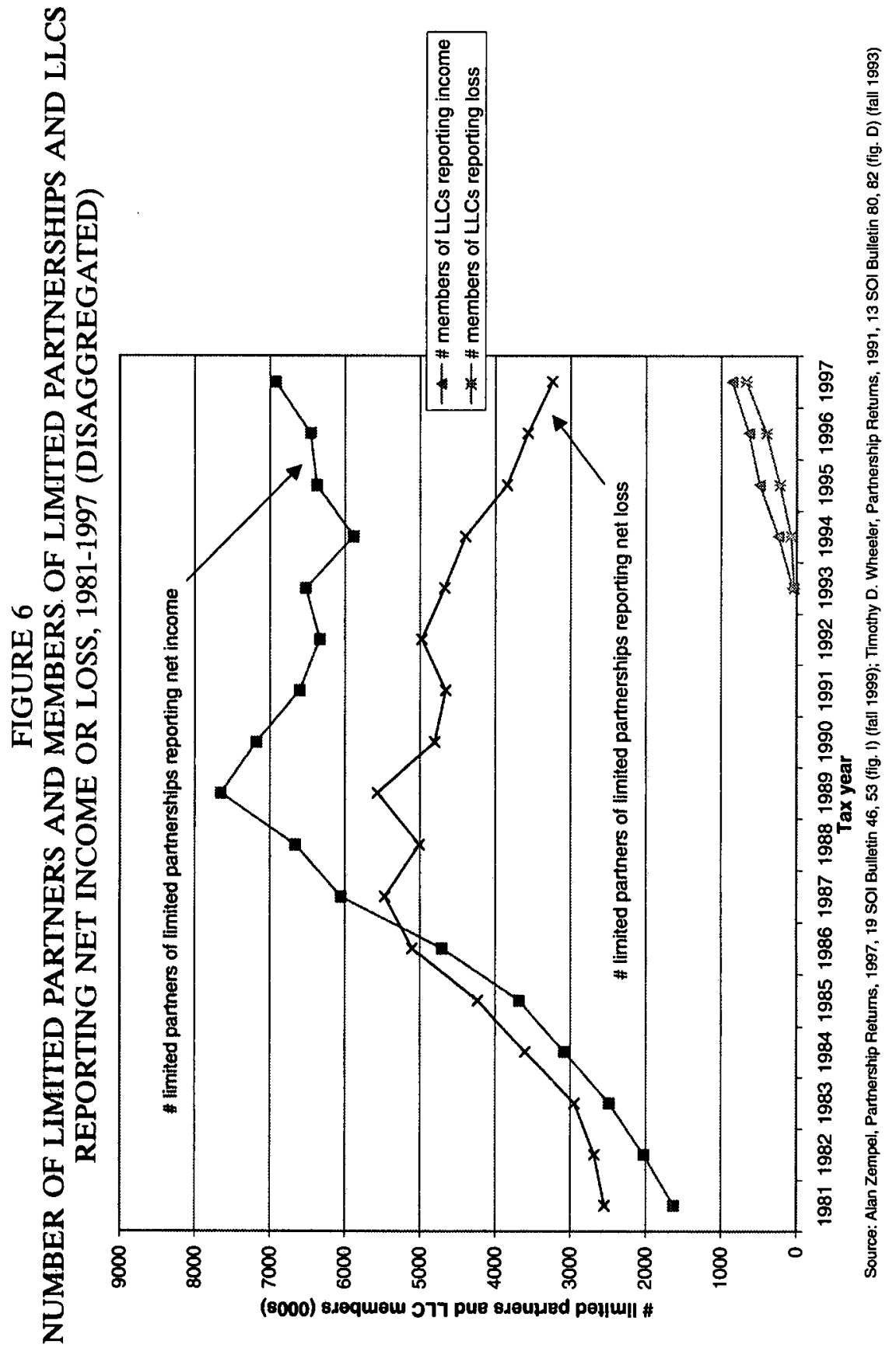




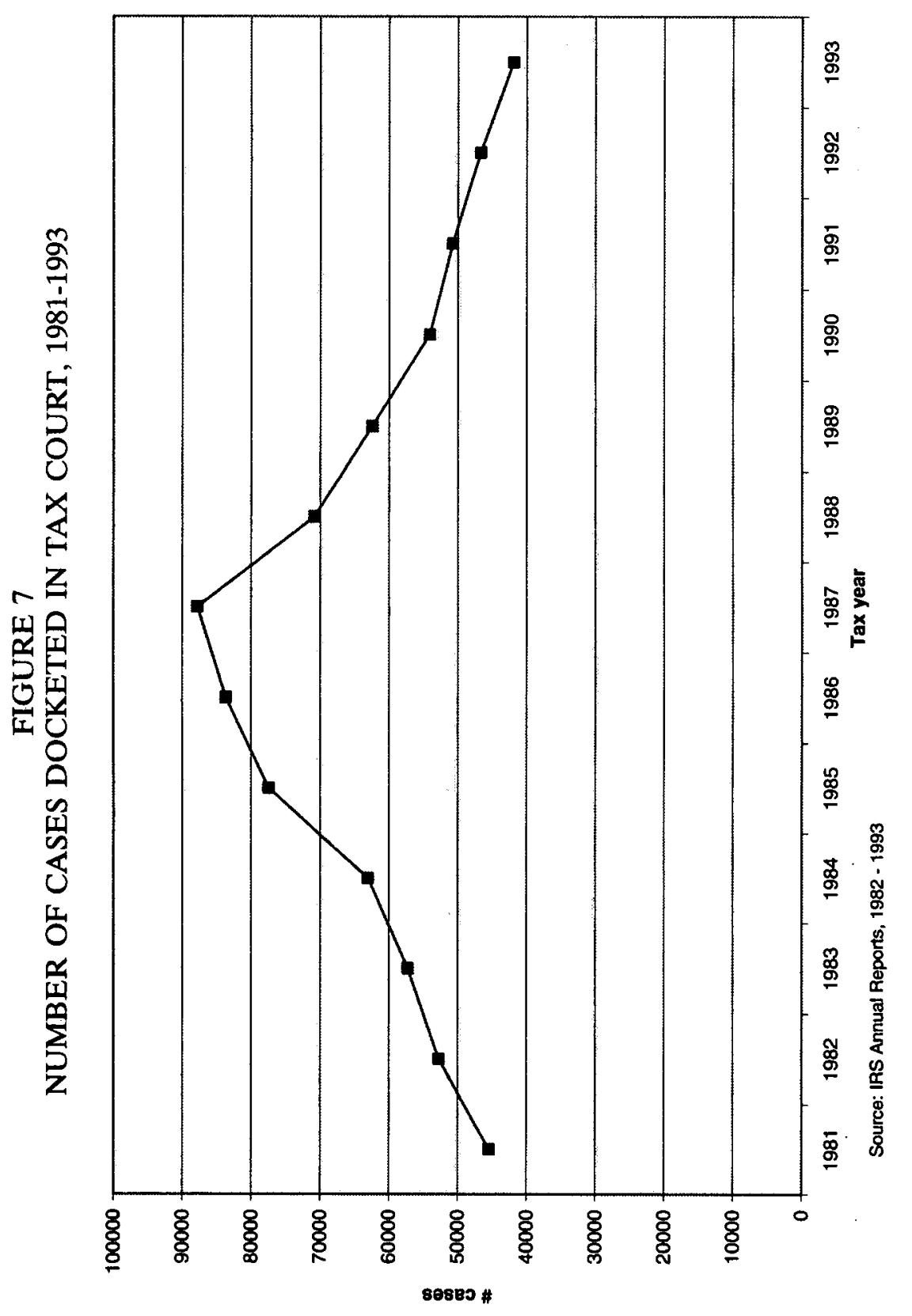


Essay 


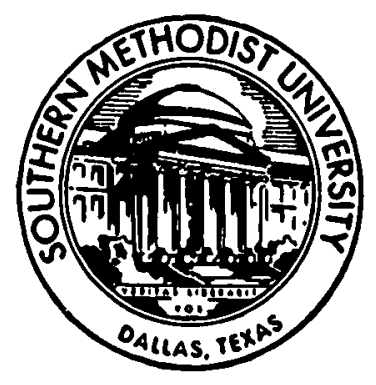

